\title{
How to kickstart a national biobanking infrastructure - experiences and prospects of BBMRI-NL
}

\author{
M. Brandsma, F. Baas, P.I.W. de Bakker, E.P. Beem, D.I. Boomsma, J. Bovenberg, \\ B. Bueno-de-Mesquita, C. van Duijn, L.A. Kiemeney, O. Klungel, P.W. de Leeuw, \\ F.E. van Leeuwen, J. Ridder-Numan, R.P. Stolk, P.E. Slagboom, M. Swertz, \\ C. Wijmenga and G.J.B. van Ommen, on behalf of BBMRI-NL \\ Correspondence: Margreet Brandsma, LUMC, Department of Human Genetics, zone S-4-P, P.O. Box 9600, 2300 RC Leiden, the Netherlands \\ E-mail: m.brandsma@LUMC.NL Telephone:+31715269412
}

Acknowledgements: BBMRI-NL is a Research Infrastructure financed by the Dutch government (NWO 184.021.007). Competing interests: Professor van Ommen is scientific director; Dr. Brandsma is program manager at BBMRI-NL.

\section{INTRODUCTION: THE IMPORTANCE OF SCALE}

Biobanking is essential for science-based health care solutions in the $21^{\text {st }}$ century. In order to develop better diagnostics, treatments and cures for diseases a deeper understanding is needed of genetic and environmental pathways causing disease, including mechanisms that protect people from becoming ill. Scientific research aimed at these issues depends on the availability of a broad spectrum of high quality human biological samples related to health and disease, accompanied by clinical, environmental and lifestyle data. Biobanks provide these essential resources.

In 2006 the Royal Netherlands Academy of Arts and Sciences published the results of a foresight study on Multifactorial Diseases in the Genomics Era. The study focused on scientific opportunities in the causes, course and prevention of multifactorial chronic disorders, including the necessary research infrastructure. It concluded that in order to be successful an adequate amount of good quality biological material and data had to be available. It also concluded that existing biobanks in the Netherlands and Europe contained sufficient amounts of samples and data to perform more detailed analyses. In order to use these, biobanks had to be optimized and linked to each other. Data and material had to be made mutually comparable, necessitating optimization of phenotype descriptions and data registration, as well as standardization of quality and storage of biological material. In addition, legal and ethical aspects had to be clarified, sufficient funding had to be made available and the public had to be properly informed. Last but not least, opportunities for European collaboration had to be explored (1).

In the same year, the European Roadmap for Research Infrastructures was produced by the European Strategy Forum on Research Infrastructures (ESFRI). This provided a strong impulse for integration of biobanks at the European level. Creating a network of existing and new biobanks and molecular resources was identified as one of the priorities in the field of Biomedical and Life Sciences (2). The European biobanking community responded to this call in 2007 and the preparatory phase of the European Biobanking and Biomolecular Resources Research Infrastructure
BBMRI started at the European level in early 2008 with funding from the European Commission. In its preparatory phase (2008-2011), plans were developed for a distributed research infrastructure with operational units in all participating countries (3).

The Dutch National Roadmap for Large-scale Research Facilities which was published later in 2008 indicated the Dutch node of BBMRI, BBMRI-NL, as top-priority (4). It received 22.5 million Euros for its initial three year period from NWO, The Netherlands Organization for Scientific Research.

In this article we outline the Dutch experience in biobanking: how a national network of biobanks, BBMRI-NL, was set up in the Netherlands and the results achieved since its initiation in 2009 .

\section{PARTICIPATING BIOBANKS}

BBMRI-NL unites over 150 Dutch biobanks that contain materials and data from more than 500,000 individuals. BBMRI-NL does not initiate new biobanks or fund maintenance, but focuses on connecting, harmonizing and enriching existing and newly emerging biobanks (5).

The strength of BBMRI-NL lies in its broad spectrum of participating biobanks, ranging from specialized small-scale clinical to large, professionally operated population-based cohorts. Some of these were initiated several decades ago and contain valuable longitudinal information. Renowned examples are the Netherlands Twin Registry (6) and The Rotterdam Study (7).

The number of participating biobanks has steadily increased over the past two years, underscoring the field's enthusiasm for BBMRI-NL's approach. Initially 125 biobanks participated, with a total number of 395,063 participants. In the summer of 2011 this number had already increased to more than 150 biobanks $(+20 \%)$ with a total number of 508,334 participants $(+29 \%)$. Most of these biobanks also participate in BBMRI's 'catalogue of European disease-oriented biobanks' (8) and the international $\mathrm{P}^{3} \mathrm{G}$ network of population-based biobanks (9). All have DNA available, many also contain other types of biological material such as RNA, plasma, serum, urine or specific 
Table 1. Overview of biobanks participating in BBMRI-NL (June 2011).

\begin{tabular}{lcr}
\hline Topic & $\begin{array}{c}\text { Number of } \\
\text { biobanks }\end{array}$ & $\begin{array}{c}\text { Number of } \\
\text { subjects }\end{array}$ \\
\hline Population, development, birth and growth & 31 & 257,059 \\
Aging (as specific focus; the above also cover older persons, $~ 30-40 \%)$ & 3 & 6,859 \\
Asthma, allergy & 12 & 26,804 \\
Cancer & 23 & 38,991 \\
Cardiovascular & 23 & 101,451 \\
Dermatology & 3 & 450 \\
Diabetes, metabolic syndrome, nutrition, storage disorders & 10 & 6,857 \\
Gastrointestinal and urinary system disorders & 7 & 19,670 \\
Infection, resistance & 8 & 9,600 \\
Hemostasis, thrombosis & 5 & 6,760 \\
Neurological, neurodegenerative & 9 & 13,701 \\
Rheumatoid disease & 5 & 5,669 \\
Psychiatric, behavioral & 12 & 14,463 \\
\hline Total & 151 & 508,334 \\
\hline
\end{tabular}

Table 2. Three major complementary biobanking initiatives in the Netherlands.

\begin{tabular}{ll}
\hline Project & Aim \\
\hline BBMRI-NL & $\begin{array}{l}\text { Focus on enrichment and harmonization of existing biobanks to increase their scientific, } \\
\text { economic and societal value, and improve accessibility and utility, e.g. by linking with } \\
\text { other biobanks. Number of subjects included (2011): over 500,000, up to } 20 \text { years follow- } \\
\text { up.Responsible for creating the Dutch national hub of BBMRI. }\end{array}$ \\
& $\begin{array}{l}\text { Focus on creating common processes and infrastructure in and between University Medical } \\
\text { PSI }\end{array}$ \\
& $\begin{array}{l}\text { Centres (UMCs) highly integrated with the health care process; building a standardized } \\
\text { clinical sample and data collection as a shared facility between UMCs. }\end{array}$ \\
LifeLines & $\begin{array}{l}\text { Focus on building a professional, three-generation, population biobank infrastructure with } \\
\text { national relevance and accessibility, based on a large population }(165,000) \text { from the North- }\end{array}$ \\
& Netherlands, to be followed during 30 years.
\end{tabular}

types of tissue. A general overview of the types of biobanks is presented in Table 1. A BBMRI-NL online catalogue with basic information on all participating biobanks is under construction (10).

Since 2007 the Dutch government has contributed to building a research infrastructure by awarding major grants to the String of Pearls Initiative (PSI) (11) and LifeLines (12), which have goals complementary to BBMRI-NL. The three initiatives work closely together. Their aims are described in Table 2.

\section{GOVERNANCE AND ORGANIZATION}

BBMRI-NL is a national consortium, uniting the organizations that own the abovementioned biobanks. These are the eight University Medical Centres (UMCs), PSI, the Netherlands Cancer Institute, the National Institute for Public Health and the Environment (RIVM), VU University Amsterdam and Utrecht University Pharmaceutical Department. A consortium agreement describing the strategy and goals of the collaboration, governance, funding conditions and policies for handling issues related to intellectual property was signed by the boards of all parties. Scientific and strategic aspects are decided upon by a steering committee, with leading scientists from all participating organizations as members. The committee had monthly meetings in the initiating phase. General progress and far-reaching strategic decisions are the responsibility of the Board of Governors, which consists of members of the boards of all participating organizations.

The core management of BBMRI-NL, formed by the authors of this article together with vice chairs of the steering committee Professor Bart Kiemeney (UMC St Radboud Nijmegen) and Professor Cisca Wijmenga (Groningen UMC), is in charge of day-today operations. A small central office takes care of administrative issues and communication, including the website, the newsletter 'Hub' and the annual 'Connecting Biobanks' conference. In order to safeguard synergy with international biobanking initiatives, an International Scientific Advisory Board (ISAB), consisting of international experts and chaired by Professor Bob Löwenberg (Erasmus MC Rotterdam), counsels BBMRI-NL on strategic issues (13).

The four main pillars of BBMRI-NL are harmonization, enrichment, data management and analysis, and ethical, legal and societal issues (ELSI). Figure 1 illustrates the budget distribution among the four pillars. 
Table 3. Example of the content of an imaginary 'ideal biobank'.

\begin{tabular}{lll}
\hline Phenotypes & Biomaterials & Genotypes and other measurements \\
\hline Clinical data & DNA & DNA sequences \\
Anthropometric data & Tissue-RNA & Genome Wide Association (GWA) \\
Lifestyle data & Plasma & Transcriptomics (expression data) \\
Environmental data & Serum & Proteomics \\
Medication & Cerebrospinal liquid & Metabolomics \\
Family history & Urine & Pharmacogenomics \\
Biomarkers & Faeces & Imaging data \\
\hline
\end{tabular}

\section{HARMONIZATION}

Differences in sample and data collection, especially concerning phenotype data, can be an obstacle in largescale cooperation between biobanks. The disparate ways to describe lifestyle aspects is a case in point. Differences in sample storage and database structure can cause compatibility problems. There may be legal differences to be considered as well. For example, the permissions obtained from participants may not cover the goals of a collaborative study. Harmonization therefore requires cooperation on various levels among professionals of a different background: scientists and clinicians, technicians and ICT professionals, epidemiologists and lawyers. Continuous efforts are needed to solve not only current problems, but also to make BBMRI-NL 'future proof'.

\section{ENRICHMENT}

The 'ideal biobank' (Table 3) does not exist, since biobanks are always 'work in action'. Their content needs to be continuously enriched with additional data and materials in order to increase their value for research. This can be achieved in various ways. Missing materials or data can be retrieved if other databases that include the same patient population exist. Pharmacological data for example may be stored in another database, or extra data can be found if the same patients participate in a clinical study. Enrichment can also be achieved through the application of bioinformatics, analyzing existing data to calculate (impute) missing information. The successful application of these techniques requires large numbers of samples, again underlining the importance of cooperation between biobanks.

\section{DATA MANAGEMENT AND ANALYSIS}

Large efforts have already been made to develop tools and techniques for data management and analysis. In the near future, even more sophisticated ways to gain knowledge from data will be developed. BBMRI-NL invests in both hardware and software, and not least in talent, to optimise bio-informatics support for national and international biobanking and related biomedical studies. Through cooperation with the biobanking platform of the Netherlands Bioinformatics Center (NBIC) and the European ELIXIR infrastructure, smart solutions for complex problems are shared and put to use.
Pillars of BBMRI-NL

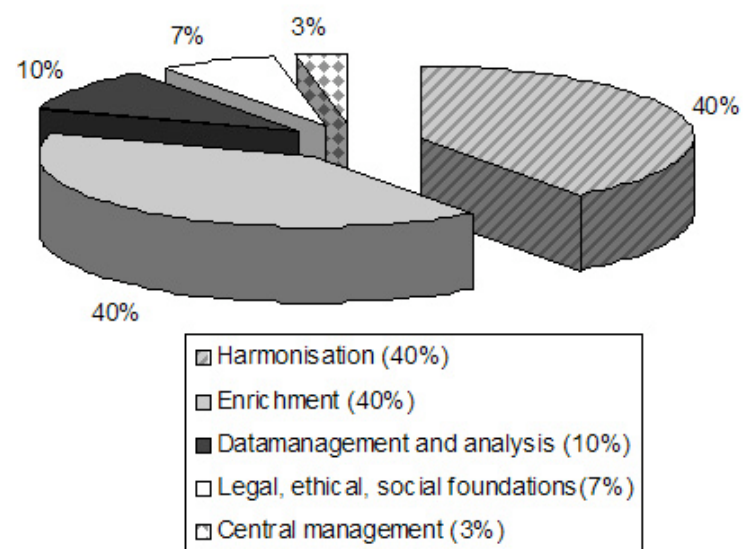

Figure 1. Budget distribution.

Within the European framework, the various challenges concerning privacy and pseudonymisation are being addressed.

\section{ETHICAL, LEGAL AND SOCIETAL ISSUES}

The overall public opinion in the Netherlands, for instance about further use of human tissue remaining after diagnostic procedures, is largely favourable (14). BBMRI-NL builds on that trust, showing the benefits of biomedical research made possible through biobanking. Sensitive issues concerning privacy, the right to 'opt-out' from participation, various ethical implications and commercial use of data and materials must be addressed in a transparent way.

Every participating biobank has its own legal and ethical foundation, ensuring participants that their rights concerning their donated biospecimens and personal data will be respected. Large-scale cooperations like BBMRI-NL and BBMRI-EU add extra complexity to the legal and ethical issues that can be raised, for instance when combined data from different biobanks are scientifically analysed or biological materials are transferred abroad.

Biobanks share many legal and ethical issues. To prevent re-invention of the wheel BBMRI-NL is developing a legal platform for sharing guidelines and experiences, a Dutch 'Legal Wiki', following the European example. This is an interactive platform for 
Table 4. Examples of BBMRI-NL Complementation projects.

\begin{tabular}{|c|c|c|}
\hline Biobank & P.I. & Aim \\
\hline Leiden Longevity Study (21) & $\begin{array}{l}\text { Professors E.P. Slagboom, } \\
\text { R.G.J. Westendorp } \\
\text { (Leiden UMC) }\end{array}$ & $\begin{array}{l}\text { Enrichment for joined GWAS with BBMRI biobanks on } \\
\text { different specific phenotypes (metabolomics, glycomics, } \\
\text { telomere size, longevity) }\end{array}$ \\
\hline $\begin{array}{l}\text { KOALA Birth Cohort Study } \\
(22)\end{array}$ & $\begin{array}{l}\text { Dr. Thijs } \\
\text { (Maastricht UMC) }\end{array}$ & $\begin{array}{l}\text { Enrichment with total and specific IgE antibody levels against } \\
\text { airway-allergenes in children and data harmonization with other } \\
\text { biobanks focusing on asthma and allergy in the Netherlands and } \\
\text { Europe. }\end{array}$ \\
\hline $\begin{array}{l}\text { EPIC-NL (part of the European } \\
\text { Prospective Investigation into } \\
\text { Cancer and Nutrition) (23) }\end{array}$ & $\begin{array}{l}\text { Dr H.B. Bueno-de- } \\
\text { Mesquita (RIVM) }\end{array}$ & $\begin{array}{l}\text { Renovation of liquid nitrogen tanks, in order to improve safety, } \\
\text { efficiency and access to samples. }\end{array}$ \\
\hline $\begin{array}{l}\text { Dutch Initiative on Crohn and } \\
\text { Colitis (ICC) (24) }\end{array}$ & $\begin{array}{l}\text { Dr R.K.Weersma } \\
\text { (Groningen UMC) }\end{array}$ & $\begin{array}{l}\text { Optimization of DNA-storage system and sample management } \\
\text { and harmonization with the String of Pearls Initiative and } \\
\text { LifeLines. Data harmonization of phenotypic characteristics and } \\
\text { genotypic enrichment with Immunochip analysis. }\end{array}$ \\
\hline PREVEND (25) & $\begin{array}{l}\text { Dr R.T. Gansevoort } \\
\text { (Groningen UMC) }\end{array}$ & $\begin{array}{l}\text { Enrichment with clinical data and linkage to the Dutch national } \\
\text { statistics agency. Database harmonization to improve interope- } \\
\text { rability of phenotype and genotype data, applying the minimal } \\
\text { core data set for biobanks of the international P3G consortium. }\end{array}$ \\
\hline
\end{tabular}

sharing up-to-date knowledge about regulations, standards and 'best practices' relating to biobanks, coordinated by legal specialist Dr Jasper Bovenberg (15).

To help guarantee the protection of both biobank participants and scientific progress, BBMRI-NL represents the Dutch biobanking community in discussions on the development of new rules and regulations. For instance, a new Dutch law concerning human tissue is currently being developed which may greatly affect biobanking practice. BBMRI-NL has provided comments regarding the draft law to the Ministry of Health (16). Via the committee on research legislation of the Dutch federation of Biomedical Scientific Societies (COREON) BBMRI-NL has also been involved in the update of the 'Code on good usage of bodily material' (17). This self-regulation code, drawn up by professionals together with patient representatives, has recently been adapted to developments in biobanking.

Another issue demanding careful legal and ethical consideration is whether and how (individual) results from biobanking research can and should be shared with participants. Building on the experience of Dutch and international biobanks, a multidisciplinary team led by Professor Cécile Janssens from Erasmus MC Rotterdam will develop a joint strategy for return of results and communication with biobank donors $(18,19)$.

\section{COMPLEMENTATION PROJECTS - SMALL BUDGET, HIGH IMPACT}

So what is BBMRI-NL's approach for enrichment and harmonization of 150 Dutch biobanks? Aiming at building up a strong research-infrastructure, a projectbased approach was chosen, with two main types of projects as building blocks.

First, following the establishment of BBMRI-NL, and noting the great and diverse need for a rapid boost of quality, accessibility and interoperability, a round of Complementation projects was conceived. The aim of these projects is to strengthen the position of individual Dutch biobanks in collaborative efforts on a national and European scale. They focus on harmonization and/or enrichment, with a financial scope of 50,000 Euro per project for a period of one year. At relatively low cost and by a very rapid procedure (approximately three months), these projects provide a major impetus towards the availability of high quality data and material for BBMRI.

A first group of 43 Complementation projects was selected after a call for proposals in 2010 , with a total budget of 2 million Euros. The aims of these projects fall roughly into three categories: (1) genomic enrichment and harmonization; (2) phenotypic enrichment and harmonization; and (3) harmonization of sample and data storage, management and accessibility.

Genomic enrichment is a major aim in $52 \%$ of the projects, ranging from isolation and quantification of DNA in biological material that is already available to Genome Wide Association analysis, construction of Tissue Micro-Arrays and Whole-exome sequencing. An equally important aim (56\% of the projects) is enrichment and harmonization of phenotypic data, for instance by measuring blood-based biomarkers, determining lifestyle and environmental risk factors, including clinical data and linking to registries, such as pharmacy records. The third aim, involving $26 \%$ of the projects, is harmonization of sample and data storage, management and accessibility. Some projects combine different aims. A few examples of Complementation projects are listed in Table 4. A complete overview can be found on the website (20).

These projects are hugely popular, due to the lowthreshold/high-need approach, and further rounds are 
Table 5. BBMRI-NL Rainbow projects (November 2011).

\begin{tabular}{|c|c|c|}
\hline Number & Title & Principal Investigators \\
\hline 1 & Genome of the Netherlands (GoNL) & Professor C. Wijmenga \\
\hline 2 & Dynamic bioinformatics infrastructures for biobank enrichment & Dr M. Swertz \\
\hline 3 & $\begin{array}{l}\text { A nation-wide functional genomics infrastructure enabling mechanistic } \\
\text { insights into complex disease phenotypes }\end{array}$ & $\begin{array}{l}\text { Dr B. Heijmans, Dr L. Franke, Dr A. } \\
\text { Isaacs, Dr R. Jansen }\end{array}$ \\
\hline 4 & $\begin{array}{l}\text { Infrastructure for the application of metabolomics technology in } \\
\text { epidemiology }\end{array}$ & $\begin{array}{l}\text { Professors P.E. Slagboom, D.I. } \\
\text { Boomsma, C. van Duijn }\end{array}$ \\
\hline 5 & $\begin{array}{l}\text { A national infrastructure for linkage of biobanks to medical and } \\
\text { socioeconomic registries: an integrative approach }\end{array}$ & Professor J.H. Smit, Dr O.H. Klungel \\
\hline 6 & $\begin{array}{l}\text { Towards a joint strategy for the return of results and optimal communication } \\
\text { with biobank donors }\end{array}$ & Professor C. Janssens \\
\hline 7 & $\begin{array}{l}\text { Linking tumor tissue samples to Dutch cohort studies for advancing } \\
\text { molecular pathological epidemiology }\end{array}$ & Professor P.A. van den Brandt \\
\hline 8 & Dutch National Tissue Portal (DNTP) & $\begin{array}{l}\text { Professor G.A. Meijer, Dr F.J. van } \\
\text { Kemenade, Dr L.I.H. Overbeek }\end{array}$ \\
\hline 9 & Nutritional enrichment and harmonization of the Dutch Cohort Infrastructure & Dr H.B. Bueno-de-Mesquita \\
\hline
\end{tabular}

foreseen. The success is partly due to the virtual lack of funding for this type of infrastructural upgrading from other sources, since it is not directly linked to specific research questions. Nevertheless, a number of scientific publications as a direct result of these investments are already underway and we expect many more, including possible clinical applications.

Taken together these relatively small projects have a major qualitative and quantitative impact, enriching and harmonizing over 300,000 samples in over 40 Dutch biobanks, all part of the national infrastructure and involved in at least as many European and international networks.

\section{RAINBOW PROJECTS - A NATIONWIDE APPROACH}

BBMRI-NL Rainbow projects aim at harmonization and enrichment, not of individual biobanks, but on a national scale. The financial scope of these collaborative efforts of biobanks and research centres generally falls between one to two million Euros.

An example is 'Genome of the Netherlands' (GoNL). The aim of this project, which started in 2010, is to determine the genetic profile of the Dutch indigenous population by DNA-sequencing of 750 Dutch individuals, 250 trios of two parents and an (adult) child. GoNL is a consortium of five UMC's, led by Professor Cisca Wijmenga from Groningen. The sequencing work is done by BGI Hong Kong. The trio-based design coupled with intermediate coverage sequencing enables the generation of a high-quality reference panel for imputation in Dutch GWAS data sets, the development of novel tools for family-based sequencing studies, and an unprecedented level of accuracy of the haplotypes for population genetic analyses.

A second Rainbow project 'Dynamic Bioinformatics', which is closely linked to GoNL, aims to build a national infrastructure for data management and analysis by harmonizing bioinformatics methods, databases, software and formats. Dutch biobanks are enriched with new models, software and tools for next generation sequencing data with scalable data archives, flexible and large scale processing pipelines and easyto-connect systems for data exchange. Five UMC's are involved in this project, as well as the Netherlands Bioinformatics centre (NBIC) and the String of Pearls Initiative. Project leader is Dr Morris Swertz from Groningen UMC. The project is interlinked with European and global efforts such as P3G, EBI, ELIXIR, ENGAGE and BioSHaRE-EU.

Other Rainbow projects aim, for instance, at linkage of biobanks to medical and socio-economic registries, at building an infrastructure for harmonization, processing and analysis of metabolomics data from different platforms in biobank material or at creating nationwide functional genomics database with genome-wide genetic, transcriptomic and epigenomic data in Dutch biobanks. An overview is given in table 5 .

\section{Prospects}

BBMRI's next challenge will be to consolidate the infrastructure at the European level by becoming a European Research Infrastructure Consortium (ERIC) (26). The Dutch government has committed itself to becoming a partner in this European legal entity by signing a Memorandum of Understanding (MoU).

Another major challenge will be to facilitate the development of clinical applications. Although in general Dutch citizens and patients are highly motivated to participate in biobanking efforts for scientific and medical purposes, they show a much more critical attitude towards providing material and data to commercial parties (14). A transparent policy is essential to safeguard the trust of patients and citizens (27) BBMRINL will follow the concept of 'Expert Centres' which has been developed by BBMRI at the European level and aims at establishing public-private partnerships in the pre-competitive, not-for profit field. 


\section{REFERENCES}

1. Royal Dutch Academy of Arts and Sciences. Multifactorial Diseases in the Genomics Era (Amsterdam 2006). [Foresight study in Dutch, with English summary]. http://www.knaw.nl.

2. European Roadmap for Research Infrastructures Report 2006. ftp://ftp.cordis.europa.eu/pub/esfri/docs/esfriroadmap-report-26092006 en.pdf.

3. Yuille M, van Ommen GJ, Bréchot C, Cambon-Thomsen A, Dagher G, Landegren U, et al. Biobanking for Europe. Brief Bioinform 2008; 9: 14-24.

4. The Netherlands' Roadmap for Large-Scale Research Facilities (Amsterdam 2008). http://english.minocw.nl/ documenten/Dutch\%20Roadmap\%20Eng.pdf.

5. Brandsma M, van Ommen GJ, Wijmenga C, Kiemeney LA. Dutch government invests in existing biobanks [in Dutch]. Ned Tijdschr Geneeskd 2010; 154: A2825.

6. Willemsen G, de Geus EJ, Bartels M, van Beijsterveldt CE, Brooks AI, Estourgie-van Burk GF, et al. The Netherlands Twin Register biobank: a resource for genetic epidemiological studies. Twin Res Hum Genet 2010; 13 (3): 231-45.

7. Hofman A, van Duijn CM, Franco OH, Ikram MA, Janssen HL, Klaver CC, et al. The Rotterdam Study: 2012 objectives and design update. Eur J Epidemiol 2011; 26 (8): 657-86.

8. Wichmann HE, Kuhn KA, Waldenberger M, Schmelcher D, Schuffenhauer S, Meitinger T, et al. Comprehensive catalog of European biobanks. Nat Biotechnol 2011; 29 (9): 795-7.

9. Knoppers BM, Fortier I, Legault D, Burton P. The Public Population Project in Genomics (P3G): a proof of concept? Eur J Hum Genet 2008; 16 (6): 664-5. See also http://www.p3gobservatory.org/.

10. http://www.bbmri.nl/en-gb/catalogue-of-biobanks.

11. Talmon JL, Ros MG, Legemate DA. PSI: The Dutch Academic Infrastructure for shared biobanks for translational research. Summit on Translat Bioinforma 2008: 110-4.

12. Stolk RP, Rosmalen JG, Postma DS, de Boer RA, Navis G, Slaets JP, Ormel J, Wolffenbuttel BH. Universal risk factors for multifactorial diseases: LifeLines: a three-generation population-based study. Eur J Epidemiol 2008; 23 (1): 67-74.

13. For a list of members see http://www.bbmri.nl/en-gb/about-bbmri-nl/organisation/isab.

14. Geesink I, Steegers C. Nader gebruik nader onderzocht. Zeggenschap over lichaamsmateriaal [Report in Dutch]. Rathenau Institute, The Hague, 2009.

15. Bovenberg JA. Legal pathways for cross-border research: building a legal platform for biomedical academia. Eur J Hum Genet 2007; 15 (5): 522-4. See also http://www.legalpathways.eu/.

16. Forsberg JS, Hansson MG, Eriksson S. Biobank research: who benefits from individual consent? BMJ 2011; 343: d5647.

17. FEDERA (2011) Gedragscode Goed Gebruik. Gedragscode verantwoord omgaan met lichaamsmateriaal ten behoeve van medisch-wetenschappelijk onderzoek [Report in Dutch].

18. Murphy J, Scott J, Kaufman D, Geller G, LeRoy L, Hudson K. Public expectations for return of results from large-cohort genetic research. Am J Bioeth 2008; 8 (11): 36-43.

19. Meulenkamp TM, Gevers SK, Bovenberg JA, Koppelman GH, van Hylckama Vlieg A, Smets EM. Communication of biobanks' research results: what do (potential) participants want? Am J Med Genet 2010; 152A (10): 2482-92.

20. http://www.bbmri.nl/nl-nl/activiteiten/projecten/85-complementatieprojecten-2010.

21. Schoenmaker M, de Craen AJ, de Meijer PH, Beekman M, Blauw GJ, Slagboom PE, Westendorp RG. Evidence of genetic enrichment for exceptional survival using a family approach: the Leiden Longevity Study. Eur J Hum Genet 2006; 14 (1): 79-84.

22. Kummeling I, Thijs C, Penders J, Snijders BE, Stelma F, Reimerink J, et al. Etiology of atopy in infancy: the KOALA Birth Cohort Study. Pediatr Allergy Immunol 2005; 16 (8): 679-84. See also http://www.koalastudy.nl/.

23. Riboli E, Hunt KJ, Slimani N, Ferrari P, Norat T, Fahey M, et al. European Prospective Investigation into Cancer and Nutrition (EPIC): study populations and data collection. Public Health Nutr 2002; 5 (6B): 111324. See also http://epic.iarc.fr.

24. Weersma RK, Stokkers PC, van Bodegraven AA, van Hogezand RA, Verspaget HW, de Jong DJ, et al. Dutch Initiative on Crohn and Colitis (ICC). Molecular prediction of disease risk and severity in a large Dutch Crohn's disease cohort. Gut 2009; 58 (3): 388-95.

25. Diercks GF, Janssen WM, van Boven AJ, Bak AA, de Jong PE, Crijns HJ, van Gilst WH. Rationale, design, and baseline characteristics of a trial of prevention of cardiovascular and renal disease with fosinopril and pravastatin in nonhypertensive, nonhypercholesterolemic subjects with microalbuminuria (the Prevention of REnal and Vascular ENdstage Disease Intervention Trial [PREVEND IT]). Am J Cardiol. 2000; 86 (6): 6358. See also http://tcc.umcg.nl/en/61/PREVEND.html.

26. http://www.bbmri.eu.

27. BBMRI Stakeholder's Forum (Brussel, Sept. 2009), http \|www.bbmri.eu/index.php/stakeholders-forum. 